\title{
DEBT FINANCING AND IMPORTANCE OF FIXED ASSETS AND GOODWILL ASSETS AS COLLATERAL: DYNAMIC PANEL EVIDENCE
}

\author{
Bolaji Tunde MATEMILOLA ${ }^{1}$, Rubi AHMAD² \\ ${ }^{1}$ Faculty of Economics and Management, Universiti Putra Malaysia, \\ 43400, Serdang, Malaysia \\ ${ }^{1,2}$ Department of Banking and Finance, Faculty of Business and Accountancy, \\ University of Malaya, 50603 Kuala Lumpur, Malaysia \\ E-mails:1'mateb4life@yahoo.com (correspondingauthor); ${ }^{2}$ rubi@um.edu.my
}

Received 18 October 2012; accepted 31 January 2013

\begin{abstract}
This article analyses the effect of fixed assets and goodwill assets on South African firms' debt ratios. The difference and system generalized method of moment estimation results reveal that fixed assets and goodwill assets have significant and positive relationship with firms' debt ratios. To secure long-term debt, fixed assets and goodwill assets are required as collateral by creditors. Our results show firms' adjust to long-run optimal debt level, but at a slow adjustment rate. Our results suggest there are costs preventing South African firms from adjusting faster to their long-run optimal debt level. The practical implication of the paper is that policy makers should promote policies that encourage further development of the capital market. Moreover, firms need both fixed assets and goodwill assets as collateral to raise the desired optimal debt that maximizes firm value.
\end{abstract}

Keywords: capital structure, debt ratio, trade-off theory, fixed assets; goodwill assets, panel GMM.

JEL Classification: G32, G33.

\section{Introduction}

At moderate levels, debt increases firm value in the real world where firms can take advantage of tax savings from debt financing. However, higher debt finance leads to financial distress and bankruptcy. Especially during a recession like the recent financial crisis, firms with high debt in their capital structure face increased risk of bankruptcy. The trade-off theory argues market imperfections such as bankruptcy and transaction costs make the capital structure (debt - equity mix) relevant. Specifically, the dynamic trade-off theory argues there is a difference between target debt and observed debt. Firms correct any deviation to avoid bankruptcy at high debt level. In South Africa, there are cases of firms going bankrupt because of excessive debt (Ezeoha, Botha 2012; 
Akinboade, Makina 2009). This bankruptcy problem is explainable using trade-off theory and dynamic trade-off theory of capital structure.

Trade-off theory is static, but firms in real world run for many years, and in changing environments. Specifically, firms in South Africa operate in an economic and business environment that changes rapidly as well as business cycles stages from 1945 to 2009 (Akinboade, Makina 2009). Therefore, capital structure of firms in South Africa would change with up and down movements of the business cycles. Thus, this suggests a need to analyze the effect of fixed assets and goodwill assets on South African firms' debt using dynamic model. To the best of our knowledge, studies that analyze the effect of fixed assets and goodwill assets on South African firms' debt are hard to find.

Specifically, the main purpose of this study is to analyze the effect of fixed assets and goodwill assets on South African firms' debt ratios. We add goodwill assets to determinants of debt because banks accept goodwill assets (as well as fixed assets) as collateral before granting debt finance to firms. Recently, Loumioti (2011) has found that twenty-one percent of secured loan includes intangible assets such as goodwill as loan collateral. We organize the paper as follows: section 1 presents literature review. Section 2 describes the data and method. Section 3 discusses the results while the last section concludes the paper.

\section{Literature review}

The search for an optimal capital structure entails deciding on proportion of debt and equity mix in firms' capital structure, and this is one of the main tasks in the process of financial management. Theories explaining capital structure variation across firms range from capital structure irrelevance proposed by Modigliani, Miller (1958) to various relevant theories. The dynamic trade-off theory explains how firms make capital structure decisions in practice. However, empirical results remain inconclusive (Flannery, Rangan 2006). After over fifty years of strong debate, researchers are yet to reach consensus on unifying theory that could comprehensively explain many facts about how firms make capital structure decisions in the real world (Frank, Goyal 2008). This is not surprising because different theories of capital structure emphasize different issues, making it challenging to have unify theory of capital structure.

Modigliani and Miller (1958) argue capital structure is irrelevant under the assumption of a perfect capital market. If the capital market is perfect, the capital structure decision is irrelevant. However, researchers have challenged Modigliani and Miller capital structure irrelevance, based on arguments that assumption of perfect capital market is unrealistic. This leads to an interesting debate on internal versus external financing and stimulate further research in this area. Research has shown that Modigliani and Miller theory fails if we consider bankruptcy, transaction costs and agency costs (Frank, Goyal 2008). Frank and Goyal (2003) argue that Modigliani and Miller theory does not provide a realistic description of how firms should set up their capital structure. However, it provides a theoretical understanding why capital structure may be relevant. From academic question raised by Modigliani and Miller, theories such as the trade-off theory and its improved version dynamic trade-off theory of capital structure evolves. 
Myers (1984) introduces the trade-off theory of capital structure where firms trade-off the benefits of debt against the costs of debt (bankruptcy costs). Specifically, trade-off theory states optimal debt exists where marginal benefit and costs of debt are equal. The improved version- dynamic trade-off theory argues firms adjust debt to the optimal level to remove the deviation. Further, it assumes that firms have long-run optimal debt that depends on firm-specific characteristics. Firm-specific characteristics vary over firms or over both time and firms (Faulkender et al. 2012; Frank, Goyal 2008).

The dynamic trade-off theory argues adjustment costs make debt sub optimal. Therefore, firms should adjust to their optimal debt level in order to avoid bankruptcy at higher debt level (Heshmati 2001). Hovakimian et al. (2001) find that firms adjust towards an optimal debt level and this optimal debt level may change over time if firms' profitability and stock price change.

De Miguel and Pindado (2001) develop a target adjustment model that explains firm's debt in the previous period and the optimal debt level. The optimal debt level expressed as a function of well-known firm specific characteristics, such as profitability, growth and fixed assets. De Miguel and Pindado (2001) results show that Spanish firms face lower adjustment costs compare with US firms. De Miguel and Pindado (2001) findings imply Spanish firms adjust faster to optimal debt level compare with U.S firms because adjustment costs have an inverse relation to the speed of adjustment. Similarly, Fama and French (2002) argue optimal debt is difficult to observe but we can determine it. However, Generalized Method of Moments estimation gives a better estimate and adjustment speed to the optimal debt level.

Loof (2004) compares the capital structure of different types of financial systems such as market-based (USA and UK) and bank-based system (Swedish). Loof (2004) results reveal that deviation from optimal debt level is smaller for US firms using more equity to compare with Swedish firms. Leary and Roberts (2005) argue that with adjustment costs, firms rebalance their capital structure occasionally.

\subsection{Previous estimations of optimal debt}

Optimal debt is not observable but we may estimate it from the data. Researchers (Shyam-Sunder, Myers 1999; Jalilvand, Harris 1984; Taggart 1977) use the long-term average as the optimal debt level. The limit with long-term average is that debt is constant over time. However, optimal debt changes over time as firm characteristics changes. Recently, Faulkender et al. (2012), Kayhan and Titman (2007), Korajczyk and Levy (2003), Fama and French (2002) adopt a two-step estimation procedure. This allows equation for the optimal debt estimated in first stage and fitted values then substituted into the target adjustment equation. The two-stage estimation procedure problem is that errors in first stage carry forward into the second stage.

Further, Flannery and Rangan (2006) adopt single step estimation and substitute optimal equation into the target adjustment equation to estimate the optimal debt in one single equation. They use external instruments that are unreliable because of measurement bias. Specifically, Lemmon et al. (2008) suspect that lagged book debt use as an 
instrument for market debt in Flannery and Rangan (2006) study is a weak instrument. However, Hui et al. (2006) improve target debt measures because they allow target debt to depend on time and mean reverting. Nevertheless, the use of the Panel Generalized Method of Moments estimation in this study will give a better estimate of the optimal debt ratio. The next section further highlights empirical studies in developed and developing countries that find positive and negative relation between fixed assets and debt ratios.

\subsection{Empirical evidence on the relation between fixed assets and debt ratios}

Most studies in developed countries (see Rajan, Zingales 1995; Titman, Wessels 1988; Ozkan 2001 among others) find a positive relationship between fixed asset and debt, but developing countries report mixed results. For instance, Um (2001) and Wiwattanakantang (1999) report a positive relationship between fixed asset and debt in Korea and Thailand respectively. Conversely, studies of Booth et al. (2001) in ten developing countries and Huang and Song (2006) in China find that fixed asset has a negative relationship with debt. However, Booth et al. (2001) argue that the relationship between debt and fixed assets depends on the type of debt. Similarly, Bevan and Danbolt (2002) find a positive relationship between fixed assets and long-term debt in the UK. Besides, Banerjee et al. (2004) argue that UK firms have optimal capital structure. They find that fixed assets have a positive relationship with debt and all other variables carry expected signs.

The findings of the relationship between debt ratios and fixed assets do not differ much across developed countries review. This shows factors that affect the capital structure in developed countries also affect capital structure in developing countries. The result is not surprising because developed countries have institutional similarities. Conversely, developing countries have different legal and institutional traditions. Thus, financial markets in developing countries would be different compare with financial markets in developed countries. Kunt and Maksimovic (1994) examine the capital structure of largest public firms in ten developing countries, which include Africa. They use Zimbabwe, Jordan, India, Pakistan, Thailand, Malaysia, Mexico, Brazil, Turkey, and Korea as samples. Kunt and Maksimovic (1994) argue there are differences in financial market development between the United States and countries use in their study. However, variables that explain the capital structure in the United States explain capital structure in developing countries. They find evidence supporting the trade-off theory and agency theory in sampled countries. However, Kunt and Maksimovic (1994) find a negative relation between debt and fixed assets. This suggests that markets for long-term debt in developing countries do not function effectively.

Similarly, Booth et al. (2001) research if the capital structure theory has application in developing countries with different financial structure. Booth et al. (2001) employ three measures of debt ratio namely: total debt ratio, long-term book debt ratio, and longterm market debt ratio. The study shows that fixed assets have positive relationships with long-term debt ratio, but negatively related to total debt ratio. Booth et al. (2001) conclude that variables that affect debt ratios in developing countries also affect debt 
ratios in developed countries. Similarly, we expect variables that explain the capital structure in developed countries to explain the capital structure of South African firms. Specifically, we expect fixed assets to be important determinant of capital structure in South Africa.

Booth et al. (2001) point out that long-term debt ratios of developing countries are lower compared with developed countries. Booth et al. (2001) findings imply that markets for long-term debt are not effectively functioning in developing countries. They argue their results are consistent with results of Rajan and Zingales (1995). The market for long-term debt is not functioning properly in developing countries but South Africa is an exception because they have well-functioning bond market that is comparable with bond markets in developed countries. Thus, South Africa debt ratio may be similar to debt ratio in developed countries.

In India, as a developing country, Bhaduri (2002) finds that fixed assets play important role as determinant of optimal debt for Indian firms. Besides, they report large size Indian firms depend more on long-term debt. Similarly, Huang and Song (2006) examine capital structure determinants in Chinese market. They find long-term debt ratio, total debt ratio and total liability ratio have positive relationships with fixed assets. Huang and Song (2006) findings are consistent with the findings of Chen (2004). Thus, India and China firms follow the trade-off theory since fixed assets have positive relationships with debt ratios in both countries.

Recently, in Central and Eastern European countries, Delcoure (2007) find fixed assets have positive relationships with debt ratios. In addition, Delcoure (2007) find a negative relation between debt ratios and profit. Delcoure (2007) concludes the pecking order theory and the trade-off theory explain the capital structure puzzle in developing countries use as a sample in their study. Similarly, Salawu (2007) finds evidence that fixed assets have positive relationships with debt ratios. Also, Omet (2006) and Rajan and Zingales (1995) find evidence that fixed assets have positive relationships with debt ratios. However, Baner (2004) and Booth et al. (2001) find evidence that fixed assets have a negative relation with total debt ratio. Achy (2009) finds the relation between fixed assets and long-term debt is unclear.

In summary, most empirical evidence, find conflicting results. The inconsistencies in findings of past researchers suggest the need for further studies in this area. In addition, it is interesting to know the effect of goodwill assets on debt ratios. It is hard to find studies in literature that investigate the relation between goodwill assets and debt. We therefore hypothesized in the $\mathrm{H}_{1}$ form that:

$\mathbf{H}_{\mathbf{1}}$ : Fixed assets and goodwill assets have relation with long-term debt ratio.

$\mathbf{H}_{2}$ : Fixed assets and goodwill assets have relation with total debt ratio.

Past studies in the literature show differences exist in financial market development of developed and developing countries, including Africa. However, Rajan and Zingales (1995), Kunt and Maksimovic (1994), Booth et al. (2001) argue that similar factors affect the capital structure of both developing countries and developed countries. 
Nevertheless, we need more studies in Africa, a developing country, to confirm Booth et al. (2001), Kunt and Maksimovic (1994) findings that similar factors affect the capital structure of developed and developing country.

This study departs from past capital structure studies in the following ways. First, we add goodwill assets to capital structure determinants because financial institutions accept it (as well as fixed assets) as collateral before granting debt finance. Recently, Loumioti (2011) study reveals that intangible assets such as goodwill assets increase borrower's access to debt capital since it helps to reduce information asymmetry problem between lenders and borrowers. Second, the study specifies the dynamic panel model compare with the static model commonly use to conduct capital structure research in Africa. It uses the panel generalize method of moments technique that control for the influence of unobserved firm-specific effects and endogenous problem.

\section{Data and methodology}

We obtained our annual data from Bloomberg. We use top 100 listed firms on the Johannesburg Stock Exchange from 2004 to 2009. Financial firms excluded because their financial statement differs significantly from that of non-financial listed firms. Regulated firms also excluded because their debt ratio is usually higher than other nonfinancial firms are (Rajan, Zingales 1995).

Past researchers (see Rajan, Zingales 1995; Frank, Goyal 2008; Eldomiaty, Ismail 2009; Nunkoo, Boateng 2010; Matemilola et al. 2012) use balance sheet and income statement data to conduct capital structure research. Similarly, we use balance sheet and income statement data to analyze adjustment to long-run optimal debt level predicted by dynamic trade-off theory. In addition, we use two measures of debt ratio - long-term debt and total debt ratios as well as goodwill assets as an additional variable.

The study covers the period of 2004 to 2009 because there is no systemic shock in the chosen period that could significantly bias the results. All the top 100 listed firms use in this study do not have any missing values for all the years cover in this study (see Table 1). Thus, we use balanced panel data.

Table 1. Sample characteristics

\begin{tabular}{lc}
\hline Year & Number of firms \\
\hline 2004 & 100 \\
\hline 2005 & 100 \\
\hline 2006 & 100 \\
\hline 2007 & 100 \\
\hline 2008 & 100 \\
\hline 2009 & 100 \\
\hline Total & 600 \\
\hline
\end{tabular}


The study specifies the following models:

$$
\begin{aligned}
& T D_{i t}=\lambda_{i} T_{i t-1}+\beta_{1}+\beta_{2} F A_{i t}+\beta_{3} \text { Profit }_{i t}+\beta_{4} \text { Size }_{i t}+\beta_{5} \text { Goodwill }_{i t}+\beta_{6} \text { Tax }_{i t}+\eta_{i}+\mu_{i t}, \\
& L D_{i t}=\lambda_{i} L D_{i t-1}+\beta_{1}+\beta_{2} F A_{i t}+\beta_{3} \text { Profit }_{i t}+\beta_{4} \text { Size }_{i t}+\beta_{5} \text { Goodwill }_{i t}+\beta_{6} \text { Tax }_{i t}+\eta_{i}+\mu_{i t},
\end{aligned}
$$

where the subscript $i$ and $t$ represents a firm and time period respectively. We do not control for costs of debt issuance in our model because it has not changed over the sample period. Models (1) and (2) use generalized method of moments (GMM) that give better results. GMM ensures no correlation between the residuals and lagged independent variables. We use two measures of debt ratio as a proxy - ratio of long-term debt to total assets, and the ratio of total debt to total assets because there is evidence in the literature that both debt measures could give different results. In addition, we use total debt because it is a broader measure of debt that includes all liabilities claim on the firms. Profit measures as ratio of profit before interest and tax to total assets. Fixed assets measured as the ratio of fixed assets to total assets. Size measures as log of total assets. Goodwill value is available in the Bloomberg database for each year. Goodwill is measured as a log of excess market value over net operating assets each year, and tax (effective tax rate) measures as ratio of tax liability to income before tax multiply by 100 . The independent variables in both models are proxies commonly used in the literature. The study uses the book value of debt because it is not affected by price fluctuation compare with the market value of debt.

\subsection{Estimation method}

We apply Panel Generalized Method of Moments (GMM) that controls for unobserved firm-specific effects. GMM removes unobserved effects and uses instruments uncorrelated with the error term. Panel GMM is appropriate because it improves efficiency and it corrects the endogenous bias (Baltagi 2005). GMM uses moments, which make instruments uncorrelated with the error term (Ozkan 2001).

Specifically, the study uses two-step difference GMM (Arellano, Bond 1991) which give better results. In addition, we use two-step systems GMM, which improve efficiency. Blundell and Bond (1998) add moments, which make correlation between unobservable effects and difference instrument, equal zero. Recent researchers (see Faulkender et al. 2012; Nunkoo, Boateng 2010; Flannery, Rangan 2006, Ozkan 2001) use GMM estimation technique to conduct capital structure research in developed countries.

To analyze the effect of fixed assets and goodwill assets on South African firms' debt, we follow the framework of Nunkoo and Boateng (2010) with changes. Nunkoo and Boateng (2010) use difference GMM and find firms adjust to target capital structure. In this study, we add system GMM that uses difference instruments and it improves efficiency. We analyze effects of fixed assets and goodwill assets on South African firms' debt. This study departs from previous study because we add goodwill assets to the determinants of optimal debt ratio. Finance institutions are accepting goodwill assets (as well as fixed assets) as collateral to obtain long-term debt capital. Loumioti 
(2011) study reveals that intangible assets such as goodwill assets increase borrower's access to debt capital since it helps to reduce information asymmetry problem between lenders and borrowers.

After taking first difference, we remove all variables that are time-invariant, such as unobservable firm-specific effects from the model. In difference model, error term correlated with lagged dependent variable. Hence, we use higher lags of the lagged dependent variable as instruments. In addition, we use higher lag of explanatory variables as instruments. However, difference GMM estimation gives unbiased and consistent estimators if the following moment conditions hold:

$$
\begin{aligned}
& E\left[\Delta \mu_{i t} T D_{t-k}\right]=E\left[\Delta \mu_{i t} X_{t-k}\right]=0 \forall k>1, \\
& E\left[\Delta \mu_{i t} L D_{t_{-k}}\right]=E\left[\Delta \mu_{i t} X_{t_{-k}}\right]=0 \forall k>1,
\end{aligned}
$$

where $\mathrm{X}$ is explanatory variables in the model use as instruments and $\mu_{\mathrm{it}}$ is the error term. Blundell and Bond (1998) add moments, which make correlation between unobservable effects $\left(\eta_{\mathrm{i}}\right)$ and difference instruments equal zero.

\section{Results and discussions}

We report descriptive statistics and correlation in Table 2. The mean value of long-term debt is 13.00 compared to the mean value of total debt that is 20.14 . Long-term debt and total debt are in the same units (millions), thus, the reason for the difference is that total debt includes short term debt. Hence, mean value of total debt should be higher. The low correlation between variables shows little risk of multicollinearity problem in the data. We specify two models. Long-term debt ratio is the dependent variable in the model one, while the total debt ratio is the dependent variable in model two. We use two-step GMM estimates because it gives better results if based on two-step estimates.

Furthermore, second order serial correlation test and the difference Sargan test reveal that instruments are valid. Thus, we can apply the generalized method of moments. The results show there is an absence of second order serial correlation in both models. Moreover, the Sargan test and difference Sargan test show valid instruments for both models. Therefore, we continue with interpretation of GMM results.

The estimated coefficients using the difference Generalized Method of Moment are significant and have the expected sign. Lagged long-term debt shows positive sign and significant at the 1 percent level. These results support the dynamic trade-off theory that firm adjusts to optimal debt level. Similarly, lagged total debt is positive and significant at the 1 percent level (see Table 3). The lagged dependent variable coefficients are significant in both models. This indicates South African firms have optimal debt and they make an effort to adjust to long-run optimal debt level. The adjustment speed is calculated as $(1-\lambda)$, where $l$ refers to the value of the estimated coefficient of the lagged debt variable in the dynamic panel models. Firms that deviate from their optimal debt ratios will undertake an adjustment process to their optimal debt level. However, 
Table 2. Descriptive statistics

Panel A. Mean and standard deviations

\begin{tabular}{lccccccc}
\hline & LD & TD & Profit & FA & Size & Tax & Goodwill \\
\hline Mean & 13.00 & 20.14 & 12.87 & 18.52 & 7.09 & 23.73 & 2.32 \\
\hline Std. dev. & 12.66 & 14.21 & 9.24 & 5.30 & 12.19 & 13.40 & 1.16 \\
\hline
\end{tabular}

Panel B. Correlation coefficients

\begin{tabular}{lcclllll}
\hline & LD & TD & Profit & FA & Size & Tax & Goodwill \\
\hline LD & 1.00 & & & & & \\
\hline TD & 0.75 & 1.00 & & & & & \\
\hline Profit & -0.13 & -0.21 & 1.00 & & & & \\
\hline FA & 0.02 & 0.03 & 0.06 & 1.00 & & & \\
\hline Size & -0.05 & 0.06 & 0.18 & -0.02 & 1.00 & & \\
\hline Tax & -0.02 & 0.11 & 0.11 & -0.07 & 0.37 & 1.00 & \\
\hline Goodwill & 0.36 & 0.30 & -0.15 & -0.06 & -0.30 & 0.27 & 1.00 \\
\hline
\end{tabular}

Notes: Long-term debt (LD) is the ratio of long-term debt to total assets. Total debt (TD) is the ratio of total debt to total assets. Profit is the ratio of profit before interest and tax to total assets. Fixed assets (FA) is the ratio of fixed assets to total assets. Size is the log of total assets. Tax is ratio of tax liability to income before tax times 100. Goodwill assets measure as log of excess market value over net operating assets each year. We obtain goodwill values from Bloomberg.

market imperfections such as transaction costs may prevent firms from instantaneous adjustment to their optimal debt level. The adjustment speeds (calculated as $1-\lambda$ ) are slow for the lagged coefficient of long-term debt ratio $(1-0.682=0.318)$ and for lagged coefficient of total debt ratio $(1-0.601=0.399)$. The adjustment speed is slow compared with De Miguel and Pindado (2001) that reports adjustment speed of 0.79 for Spanish firms and Ozkan (2001) that reports adjustment speed of 0.55 for the UK firms. This slows adjustment speeds imply adjustment costs preventing South African firms from adjusting faster to long-run optimal debt level. Further, since adjustment speeds are slow, the results imply costs of deviating from optimal debt level may be less important for South African firms.

Besides, the results reveal that fixed assets and goodwill assets have significant and positive relationship with long-term debt and total debt. The evidence of a positive relation between fixed assets and debt ratios suggest that South African firms need to give collateral before obtaining debt capital. Specifically, the result implies that South African firms use fixed assets as collateral when negotiating borrowing, especially long term borrowing.

Additionally, the results suggest collateral (fixed assets) reduces the information asymmetry problem when firms approach banks for debt finance. Firms that have more fixed assets get long-term debt capital easily even if they do not disclose all information to 
Table 3. Generalized method of moment estimates (two-step difference GMM)

\begin{tabular}{lcc}
\hline Dependent variable & Long term debt & Total debt \\
\hline Independent variables & GMM (difference) & GMM (difference) \\
\hline $\mathrm{LD}_{\mathrm{it}-1} / \mathrm{TD}_{\mathrm{it}-1}$ & $0.682^{* * *}(12.14)$ & $0.601^{* * *}(5.74)$ \\
\hline Profit & $-0.111^{* *}(-2.45)$ & $-0.171^{* * *}(-4.03)$ \\
\hline Fixed assets & $0.080^{* *}(2.50)$ & $0.082^{* * *}(3.43)$ \\
\hline Size & $0.239^{* *}(2.49)$ & $-0.814^{* * *}(-7.49)$ \\
\hline Goodwill assets & $0.048^{* *}(2.16)$ & $0.036^{* *}(2.54)$ \\
\hline Tax & $-0.080(-1.06)$ & $-0.005(-0.10)$ \\
\hline $2^{\text {nd }}$ order serial correl. (p-value) & 0.7293 & 0.8827 \\
\hline Sargan Test (p-values) & 0.9575 & 0.5227 \\
\hline
\end{tabular}

Notes: Long-term debt (LD) is the ratio of long-term debt to total assets. Total debt (TD) is the ratio of total debt to total assets. Profit is the ratio of profit before interest and tax to total assets. Fixed assets (FA) is the ratio of fixed assets to total assets. Size is the log of total assets. Tax is ratio of tax liability to income before tax times 100 . Goodwill assets measure as log of excess market value over net operating assets each year. We obtain goodwill values from Bloomberg. The numbers in parentheses are test statistics. The model estimated using Dynamic Panel program used by Are-llano and Bond (1991). ** and *** indicate coefficient is significant at 5 and 1 percent levels respectively. Second order correlation that has $N(0,1)$ distribution, but null uncorrelated with errors. ${ }^{f}$ Standard errors are robust for difference GMM results. Sargan (1958) over identification tested and nulled that instruments are valid. Sargan (1958) test runs if the error is GMM type (Stata xtabond command). $\mathrm{N}=100, \mathrm{~T}=6$, instruments $=16$.

banks. The estimated coefficient for fixed assets is twice that of goodwill assets for the difference generalized method of moment results. The reason could be that fixed assets are more preferred as collateral when firms want to obtain long-term debt financing. However, this result is not robust in the system generalized method of moment results.

Conversely, profit is statistically significant and has a negative relationship with debt. The results of this study are consistent with the findings of Rajan and Zingales (1995), Delcoure (2007) and Salawu (2007) who find evidence that fixed assets have positive relationships with debt ratios. The results are also consistent with findings of Nunkoo and Boateng (2010), Flannery and Rangan (2006) who find evidence that firm adjust their debt ratios to long-run optimal debt level as predicted by dynamic trade-off theory. Conversely, the result contradicts findings of Baner (2004) and Booth et al. (2001), and who find evidence that fixed assets has a negative relationship with debt.

\subsection{Robustness of the results}

We conduct a number of tests to examine the robustness of the results. First, the study examines the sensitivity of the results to alternative model specification. Specifically, the study uses system-generalize method of moments (System GMM). We find lagged total debt and long-term debt are significant at 1 percent (see Table 4). This suggests 
Tale 4. Generalized method of moment estimates (Two-step system GMM)

\begin{tabular}{|c|c|c|}
\hline Dependent variable & Long term debt & Total debt \\
\hline Independent variables & GMM (system) & GMM (system) \\
\hline $\mathrm{LD}_{\mathrm{it}-1} / \mathrm{TD}_{\mathrm{it}-1}$ & $0.688^{* * *} \quad(12.82)$ & $0.535 * * * \quad(4.40)$ \\
\hline Profit & $-0.102 * *(-2.67)$ & $-0.154 * * *(-6.03)$ \\
\hline Fixed assets & $0.030 * *(2.06)$ & $0.061 * * \quad(2.77)$ \\
\hline Size & $-0.054 \quad(-0.53)$ & $-0.068 \quad(-0.46)$ \\
\hline Goodwill assets & $0.047 * *(2.01)$ & $0.029 * * \quad(2.26)$ \\
\hline Tax & $-0.021 \quad(-1.19)$ & $(0.78)$ \\
\hline $2^{\text {nd }}$ order serial correl. ( $\mathrm{p}$-value) & 0.4906 & 0.2192 \\
\hline Difference Sargan Test (p-values) & 0.1427 & 0.2113 \\
\hline
\end{tabular}

Notes: Long-term debt (LD) is the ratio of long-term debt to total assets. Total debt (TD) is the ratio of total debt to total assets. Profit is the ratio of profit before interest and tax to total assets. Fixed assets (FA) is the ratio of fixed assets to total assets. Size is the log of total assets. Tax is ratio of tax liability to income before tax times 100 . Goodwill assets measure as $\log$ of excess market value over net operating assets each year. We obtain goodwill values from Bloomberg. The numbers in parentheses are test statistics. The model estimated using Dynamic Panel program used by Blundell and Bond (1998). ** and *** indicate coefficient is significant at 5 and 1percent levels respectively. Second order correlation that has $N(0,1)$ distribution, but null uncorrelated with errors. ${ }^{f}$ Standard errors are robust for system GMM results. Difference Sargan (1958) over identification tests and nulls that instruments are valid. Difference Sargan (1958) test runs if the error are GMM type (Stata xtdpdsys command). $\mathrm{N}=100, \mathrm{~T}=6$, Instruments $=20$.

South African firms adjust their debt to optimal debt level. Second, we perform second order serial correlation tests because generalized method of moments gives consistent estimates if there is an absence of second order serial correlation in the error terms. The test results show absence of second order serial correlation in the error terms. Thus, GMM is suitable for estimating the parameters of interest. Third, we perform Sargan test and difference Sargan test of instruments validity because GMM gives consistent estimates for valid instruments. The Sargan test indicates the instruments are valid uncorrelated with the error term. Besides, we specify dynamic panel models and use two different proxies as the dependent variable to see if the results are similar. Indeed, we find similar results. Fixed assets and goodwill assets are significant and they have positive effects on long-term debt and total debt ratios.

\section{Conclusions}

The paper analyses the effects of fixed assets and goodwill assets on South African firms' debt ratios. The results reveal fixed assets and goodwill assets are statistically significant, and positively related to long-term debt ratio. Similarly, fixed assets and goodwill assets are statistically significant, and positively related to total debt ratio. This 
implies fixed assets and goodwill assets needed as collateral for getting debt capital in South Africa. This supports findings of Loumioti (2011) that goodwill assets increase borrower's access to debt capital since it helps to reduce information asymmetry between borrowers and lenders. The size coefficients show inconsistent sign in the results. This suggests size may not be consistent determinants of capital structure in South Africa. Tax is insignificant in the results. These are not surprising because past studies also reported inconsistent results for size and tax variables.

Further, the results reveal that South African firms' adjust to long-run optimal debt level, which support dynamic trade-off theory. Lagged dependent variables show positive sign and significant at 1 percent in all results. Moreover, the study reveals that South African firms have long-run optimal debt level, but the adjustment speeds are slow. At such slow adjustment speeds, it will take South African firms longer years to close the gap between their actual debt and optimal debt level. This implies under or over leveraged firms slowly adjusts to long-run optimal debt level. The slow adjustment speeds could be that there are costs preventing South African firms from adjusting faster to long-run optimal debt level. In addition, speeds of adjustment have an inverse relation with adjustment costs. The results further imply costs of deviating from the optimal debt level may be insignificant for South African firms.

The study implies the dynamic nature of capital structure decisions deserves attention in South Africa. In general, this study shows that empirical evidence on the dynamic trade-off theory found in developed countries is also applicable to South Africa, despite the institutional differences that exist between them. Furthermore, the results imply that policy makers should identify the point beyond which further increases in debt becomes a threat to firms. Put differently, policy makers need to assess sustainable debt to identify firms that need to reduce debt in their capital structure to avoid possible bankruptcy at higher debt level. The results suggest the need for further development of the capital markets in order to reduce costs preventing firms from adjusting faster to their optimal debt ratio. Moreover, firms need both fixed assets and goodwill assets as collateral to raise the desired optimal debt that maximizes firm value.

The paper contributes to empirical research on capital structure in three ways. Firstly, the paper provides new evidence that goodwill assets are statistically significant, and positively related to debt ratios. Secondly, the paper represents one of the limited available studies that empirically analyze adjustment to long-run optimal debt level for fast growing South Africa. Third, the study apply a dynamic panel model compared with a static model commonly use to conduct capital structure research in Africa. It uses generalized method of moments techniques that address endogenous problem. We address the endogenous problem by using efficient instrumental variable techniques.

The paper applies the generalized method of moment (GMM) that addresses the endogenous problem. GMM reduces bias in estimating coefficients, but it does not address differences in firms' speed of adjustment to optimal debt level. It is possible that speeds of adjustment vary across firms, which the study does not cover. Future 
research needs to investigate how firm adjust in asymmetric way towards target debt with the use of dynamic panel threshold model. Dynamic panel threshold estimates heterogeneous speeds of adjustment in different regimes as well as test for the threshold effect. Besides, future research may consider goodwill assets as determinant of capital structure.

\section{Acknowledgement}

The authors acknowledge the anonymous reviewers and editors for helpful suggestion that imrove the paper.

\section{References}

Akinboade, O. A.; Makina, D. 2009. Econometric analysis of bank lending and business cycles in South Africa, Applied Economics 42: 3803-3811. http://dx.doi.org/10.1080/00036840802360138 Arellano, M.; Bond, S. R. 1991. Some tests of specification for panel data: Monte Carlo evidence and an application to employment equations, Review of Economic Studies 58(2): 277-297. http://dx.doi.org/10.2307/2297968

Baltagi, B. H. 2005. Econometric analysis of panel data. West Sussex: John Wiley and Sons. Baner, P. 2004. Capital structure of listed companies in Visegrad Countries, Research Seminar Paper presented at the seminar for comparative economics. Munich: LMU.

Banerjee, S.; Heshmati A.; Wihlborg, C. 2004. The dynamics of capital structure, Research in Banking and Finance 4: 275-97. http://dx.doi.org/10.1016/S1567-7915(04)04011-X

Bevan, A.; Danbolt, J. 2002. Capital structure and its determinants in the UK: a decomposition analysis, Applied Financial Economic 12(3): 159-170. http://dx.doi.org/10.1080/09603100110090073 Bhaduri, S. 2002. Determinants of corporate borrowing: some evidence from the Indian corporate sector, Journal of Economics and Finance 26: 200-215. http://dx.doi.org/10.1007/BF02755986

Blundell, R.; Bond, S. 1998. Initial conditions and moment restrictions in dynamic panel data models, Journal of Econometrics 87: 115-143. http://dx.doi.org/10.1016/S0304-4076(98)00009-8

Booth, L.; Aivazian, V.; Demirguc-Kunt, A.; Maksimovic, V. 2001. Capital structures in developing countries, Journal of Finance 56(1): 87-130. http://dx.doi.org/10.1111/0022-1082.00320

Chen, J. 2004. Determinants of capital structure of Chinese-listed companies, Journal of Business Research 57(12): 1341-1351. http://dx.doi.org/10.1016/S0148-2963(03)00070-5

Delcoure, N. 2007. The determinants of capital structure in transitional economies, Journal of International Review of Economics and Finance 16: 400-415.

http://dx.doi.org/10.1016/j.iref.2005.03.005

De Miguel, A. D.; Pindado, J. 2001. Determinant of capital structure: evidence from Spanish panel data, Journal of Corporate Finance 7: 77-99. http://dx.doi.org/10.1016/S0929-1199(00)00020-1

Eldomiaty, T. I.; Ismail, M. A. 2009. Modeling capital structure decisions in a transition market: empirical analysis of firms in Egypt, Review of Quantitative Financial Accounting 32: 211-233. http://dx.doi.org/10.1007/s11156-008-0091-x

Ezeoha, A.; Botha, F. 2012. Firm age, collateral value, and access to debt financing in an emerging economy, evidence from South Africa, South Africa Journal of Economics and Management Sciences 15(1): 55-71.

Fama, E.; French, K. 2002. Testing trade-off and pecking order predictions about dividends and debt, Review of Financial Studies 15: 1-33. http://dx.doi.org/10.1093/rfs/15.1.1 
Faulkender, M.; Flannery, M. J.; Hankins, K. W.; Smith, J. M. 2012. Cash flows and leverage adjustment, Journal of Financial Economics 103: 632-646.

http://dx.doi.org/10.1016/j.jfineco.2011.10.013

Flannery, M.; Rangan, K. 2006. Partial adjustment towards target capital structures, Journal of Financial Economics 79: 469-506. http://dx.doi.org/10.1016/j.jfineco.2005.03.004

Frank, M. Z; Goya, K. V. 2008. Trade-off and pecking order theories of debt, Handbook of Corporate Finance, Empirical Corporate Finance 2: 1-82.

Frank, M. Z; Goyal, K. V. 2003. Testing the pecking order theory of capital structure, Journal of Financial Economics 67: 217-248. http://dx.doi.org/10.1016/S0304-405X(02)00252-0

Heshmati, A. 2001.The dynamics of capital structure: evidence from Swedish micro and small firm, Research in Banking and Finance 2: 199-241.

Hovakimian, A.; Opler, T.; Titman, S. 2001. The debt-equity choice, Journal of Financial and Quantitative Analysis 36(1): 1-24. http://dx.doi.org/10.2307/2676195

Huang, S. G.; Song, F. M. 2006. The determinants of capital structure: evidence from China, China Economic Review17(1): 14-36. DOI: http://dx.doi.org/10.1016/j.chieco.2005.02.007

Hui, C. H.; Lo, C. F.; Huang, M. X. 2006. Are corporate target leverage ratios times dependent? International Review of Financial Analysis 15: 220-236.

http://dx.doi.org/10.1016/j.irfa.2005.01.001

Jalilvand, A.; Harris, R. S. 1984. Corporate behavior in adjusting to capital structure and dividend targets: an econometric study, Journal of Finance 39: 127-145.

http://dx.doi.org/10.1111/j.1540-6261.1984.tb03864.x

Kayhan, A.; Titman, S. 2007. Firms' histories and their capital structures, Journal of Financial Economics 83: 1-32. http://dx.doi.org/10.1016/j.jfineco.2005.10.007

Korajczyk, R. A.; Levy, A. 2003. Capital structure choice: macroeconomics conditions and financial constraints, Journal of Financial Economics 68: 75-109.

http://dx.doi.org/10.1016/S0304-405X(02)00249-0

Kunt, A.; Maksimovic, V. 1994. Capital structure in developing countries: evidence from ten countries, Working Paper: Policy Research Paper No. 1320. The World Bank.

Leary, M.; Roberts, M. 2005. Do firms rebalance their capital structure?, Journal of Finance 60(6): 2575-2619.

Lemmon, M. L.; Roberts, M. R; Zender, J. F. 2008. Back to the beginning: persistence and the cross-section of corporate capital structure, Journal of Finance 63(4): 1575-1608.

http://dx.doi.org/10.1111/j.1540-6261.2008.01369.x

Loof, H. 2004. Dynamic optimal capital structure and technical change, Structural Change and Economic Dynamics 15(4): 449-68. http://dx.doi.org/10.1016/j.strueco.2003.05.001

Loumioti, M. 2011. The use of intangible assets as loan collateral, Working Paper. Harvard Business School.

Matemilola, B. T.; Bany-Ariffin, A. N.; Azman Saini, W. N. W. 2012. Financial leverage and shareholder's return: evidence from South Africa corporate sector, Transition Studies Review 18(3): 601-612. http://dx.doi.org/10.1007/s11300-012-0214-x

Modigliani, F.; Miller, M. 1958. The cost of capital, corporate finance and the theory of investment, American Economic Review 48(3): 261-297.

Myers, S. C. 1984. The capital structure puzzle, Journal of Finance 39(3): 575-592.

http://dx.doi.org/10.2307/2327916

Nunkoo, P. K.; Boateng, A. 2010. The empirical determinants of target capital structure and adjustment to long-run target: evidence from Canadian firms, Applied Economics Letters 17: 983-990. http://dx.doi.org/10.1080/17446540802599671 
Omet, G. 2006. Ownership structure and capital structure: evidence from the Jordanian capital market, Corporate Ownership Control 13: 99-107.

Ozkan, A. 2001. Determinants of capital structure and adjustment to long-run target: evidence from UK company panel data, Journal of Business Finance and Accounting 28(2): 175-198. http://dx.doi.org/10.1111/1468-5957.00370

Rajan, R.; Zingales, L. 1995. What do we know about capital structure? Some evidence from international data, Journal of Finance 50: 1421-1460.

http://dx.doi.org/10.1111/j.1540-6261.1995.tb05184.x

Salawu, R. O. 2007. An empirical analysis of the capital structure of selected quoted companies in Nigeria, International Journal of Applied Economics 1(2): 16-28.

Sargan, D. 1958. The estimation of economic relationships using instrumental variables, Econometrica 26 (2): 393-415. http://dx.doi.org/10.2307/1907619

Shyam-Sunder, L.; Myers, S. C. 1999. Testing static trade-off against pecking order models of capital structure, Journal of Financial Economics 51(2): 219-244.

http://dx.doi.org/10.1016/S0304-405X(98)00051-8

Taggart, R. A. 1977. A model of corporate financing decision, Journal of Finance 32(5): 1467-1484. http://dx.doi.org/10.1111/j.1540-6261.1977.tb03348.x

Titman, S.; Wessels, R. 1988. The determinants of capital structure choice, Journal of Finance 43: 1-19. http://dx.doi.org/10.1111/j.1540-6261.1988.tb02585.x

Um, T. 2001. Determination of capital structure and prediction of bankruptcy in Korea. PhD thesis. Cornell University, Korea.

Wiwattanakantang, Y. 1999. An empirical study on the determinants of capital structure of Thai firms, Pacific Basin Finance Journal 7: 371-403.

http://dx.doi.org/10.1016/S0927-538X(99)00007-4

Bolaji Tunde MATEMILOLA is currently a PhD candidate at University Putra Malaysia and teaches corporate finance courses. He also works for Distance Learning College \& Training, UK as assessor of Business Management courses. He has taught corporate finance at University of Malaya, and has worked in the financial services industry before joining academics. He holds a Master of Arts in Finance and Investment degree from Nottingham University and Master of Science in Economics from University Putra Malaysia. His papers have been published in Transition Studies Review, Managerial Finance, and Procedia Economics and Finance.

Rubi AHMAD is an Associate Professor at University of Malaya and teaches in undergraduate and postgraduate programmes as well as supervising several doctoral students. She holds a MBA level degree specialization in finance from University of Memphis, TN, USA and a PhD in finance at Monash University, Australia. She co-authored in several chapters of four books and journal articles such as Journal of International Money and Finance, Investment Management and Financial Innovations, and Asian Academy of Management Journal. 